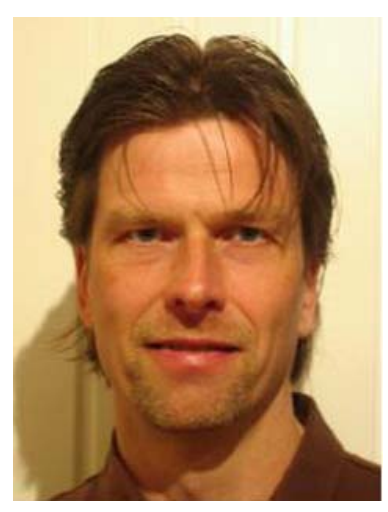

Petri Salo

\section{Vapaus ja sivistys}

I

hmiskunnan ongelmat eivät ratkenneetkaan avoimilla, vapailla ja säätelemättömillä globaaleilla markkinoilla. Taloustieteen asiantuntijat ovat laskeneet tähdet ja raidat -lipun salosta, ja nostaneet sen tilalle repaleisen valkoisen pyyhkeen. Ainakin väliaikaisesti. Markkinoilla vallitsee luottamuspula, sosiaalinen pääoma on vähissä. Jälkiviisas skeptikko tulkitsee uuden talousliberalismin Thatcherilaisen imperatiivin menneessä aikamuodossa. "There was no alternative.” Ja kas kummaa: ’There is such thing as society.” Sille lankesi takuumiehen rooli.

Vapaan markkinatalouden kulta-ajasta huolimatta julkisella sektorilla on menty kohti tiukempaa sääntelyä, hallintaa ja tilinpitoa. Vapausasteet ja vaihtoehdot ovat vähentyneet. Luonnos uudeksi yliopistolaiksi on askel tähän suuntaan. Se myötä akateeminen vapaus uuden tiedon ja ymmärryksen saavuttamisen edellytyksenä vähentyy. Akateemisen vapauden merkitystä yliopistojen menestyksekkään toiminnan lähtökohtana korostettiin edellisen laskusuhdanteen alla. Eurooppalaisten yliopistojen rehtorit allekirjoittivat Bolognan yliopiston 900-vuotisjuhlassa vuonna 1988 Magna Charta Universitatumin, jossa huomio kiinnittyi akateemisen vapauden turvaamiseen. Myös vuoden 2001 Euroopan yliopistojen liiton Salamancan sopimuksessa korostetaan akateemisen vapauden merkitystä. Akateeminen vapaus on keskeinen, Suomessa esimerkillisen säntillisesti toteutetun, Bolognan prosessin peruspilareista.

Tutustuin hiljan tutkimukseen, jossa verrattiin akateemisen vapautta, sen edellytyksiä 23 EU-maassa. Muuttujat tai "mittarit”, joiden avulla vapautta tarkasteltiin olivat seuraavat; perustuslaissa taattu sananvapaus, yliopistojen toimintaa säätelevässä laissa määritelty tutkimuksen ja opetuksen vapaus, yliopistojen hallinnollinen autonomia (tieteelliseen asiantuntijuuteen perustuva päätöksenteko, vapaus valita rehtori sekä edustajat sisäisiin hallintoelimiin) sekä pysyvät "elinikäiset” virkasuhteet. Suomi oli - taas kerran - sijalla yksi, yhdessä Tšekin, Slovenian, Unkarin sekä Espanjan kanssa. Iso-Britannia, jonne mekin Yhdysvaltojen ohella akateemisista norsunluutorneistamme kateellisina tähyilemme, oli tässä rankkauksessa viimeinen. Myös Ruotsissa akateeminen vapaus on yllättävän vähäistä. Uusi yliopistolaki tullee heikentämään ainakin yliopiston hallinnollista autonomiaa sekä henkilökunnan virkasuhteita. Akateeminen vapaus vähenee.

Aikuiskoulutusta ollaan kehittämässä ja uudistamassa. Lyhenteistä AKKU ja KEHO syntyy luovia fysiologisia assosiaatioita. Kuten julkisten palvelujen suhteen ylipäätään kehittämisen tavoitteena ja välineenä näyttää olevan monimuotoisen, laaja-alaisen ja ihmisiä lähellä olevan, parin vuosikymmenen aikana järjestelmällisesti luodun aikuiskoulutusverkoston karsiminen. Terveydenhuollon mallia seuraten myös sivistyksenhuollossa tultaneen turvautumaan ulkoistamisiin ja yksityisiin palvelutuottajiin, hankkimaan tarvittavat sivistyspalvelut vapailta markkinoilta, mahdollisesti käypään markkinahintaan. 
aikka myös Vapaan sivistystyön kehittämisohjelmassa pyritään jonkinlaiseen irtiottoon vanhasta näyttää päähuomio kuitenkin kiinnittyneen vahvasti järjestelmään ja rakenteisiin, ei ihmisiin eikä sivistymisen iloihin ja suruihin. Vahvistuneeseen Bildung as business -ajatteluun viittaa myös kentän toimijoiden puhe ja huoli käyttötaloudesta, rahoitusjärjestelmistä, tulorakenteista, maksullisesta palvelutoiminnasta ja opiskelijamaksuista.

Muihin Pohjoismaihin verrattuna suomalainen vapaa sivistystyö voi toistaiseksi hyvin. Kuntalaiset osallistuvat toimintaan ja sivistäviin huveihin yhtä innokkaasti kuin aiemmin. Osa huomattavan aktiivisesti. Vapaan sivistystyön järjestäjien keskuudessa huolet näyttävät kasvavan. Yhdeksi merkiksi olen tulkinnut keskustelun vapaan sivistystyön -käsitteestä sekä ehdotukset sen korvaamisesta jollain muulla. Käsitettä ei ole onnistuttu vuosikymmenien saatossa polttomerkitsemään osallistujien eikä päättäjien mieliin. Ainakin kansanopistokentälle ollaan valmiita luopumaan vapauden etuliitteestä.

Mutta jos nahanluomisen tielle lähdetään saattaisi olla syytä konsultoida alan asiantuntijoita. Ruotsinkielisen kauppakorkeakoulun markkinoinnin professori Christian Grönroos on todennut ongelmiin joutuneiden yritysten nimenvaihdosta: ”Nimenvaihto ei välttämättä ole se toimenpide, johon kannattaa ryhtyä ensimmäisenä. Se edellyttää koko yrityksen uudelleenorganisointia. Joskus se saattaa kuitenkin olla se ainoa toimenpide, jolla kyetään palauttamaan asiakkaiden ja rahoittajien luottamus.” Luottamuspulastahan ei vapaassa sivistystyössä kuitenkaan ole kyse? Vai onko?

Vapaan sivistystyön kentällä orastavaa keskustelua ovat herättäneet myös ns. huuhaa- ja hömppäkurssit. Muutama kansalais- ja kansanopisto näyttää koetelleen vapauden määritelmää ja rajoja. Huomiota ovat herättäneet erilaiset rajatietoon ja vaihtoehtoisiin hoitomuotoihin keskittyneet kurssit. Mutta jos vapaassa sivistystyössä suuntaudutaan tulevaisuudessa yhä vahvemmin, KEHO:n linjausten mukaisesti, kysyntälähtöisyyteen, pitänee vanha sanonta sitä tarjotaan mitä tilataan - paikkansa. Palvelun laatuhan määritellään palvelun tuottajan kyvyksi vastata asiakkaan tarpeisiin ja toiveisiin.

Olisin itse, sisältöjen ohella, huolissani siitä, että vapaan sivistystyön tarjonnasta uhkaa tulla sivistyssilppua. Kurssit ovat yhä lyhyempiä, muutaman tunnin mittaisia. Pyrkimys sivistymisen prosessien ennakoimiseen, virtaviivaistamiseen ja tiivistämiseen koskee koko aikuiskasvatuksen kenttää. Vapaata rönsyilyä ei katsota hyvällä, ei kansalaisopistojen kursseilla eikä yliopiston luennoilla. Oppimistavoitteet on pystyttävä esittämään jo kurssiesitteessä, tutkimustulokset jo tutkimussuunnitelmassa. Toimintaa säätelevissä laeissa (myös luonnoksessa uudeksi yliopistolaiksi) muotoilut ovat harvinaisen selkeät - vapaa sivistys, tutkimus, kasvatus ja opetus. Olisiko meidän syytä olla entistä lainkuuliaisempia kansalaisia - pitää tiukasti kiinni meille laissa taatuista vapauksista?

\section{PETRI SALO}

psalo@abo.fi 